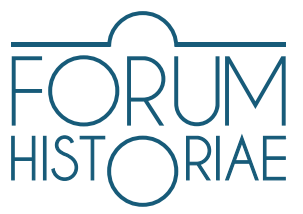

\title{
"As Mr. Schwarz is not Jewish, we are unable to handle this case." Elements of (Un)Success in Overseas Emigration from Post-war Czechoslovakia
}

\author{
Jozef Hyrja
}

\begin{abstract}
HYRJA, Jozef. "As Mr. Schwarz is not Jewish, we are unable to handle this case." Elements of (Un)Success in Overseas Emigration from Post-war Czechoslovakia.

Through the case study of the Schwarz family, this paper illustrates the complex relationship between an individual and institutions as well as the question of mutual trust-and mistrust-in the emigration process. The Schwarz family's attempt to emigrate from Czechoslovakia with the assistance of intermediary organizations provides a wealth of insight into the (dis)function of a state and its administration after the war and during a time of defining the country's approach to specific minority groups. This case provides a description of the chain of interlinked events and shifting loyalties which often occurred between the individual, intermediaries, donors or sponsors and the state. It concerns a group of Holocaust survivors who failed to regain Czechoslovak citizenship after World War II based on a specific ethnic definition of eligibility and found themselves "stateless".
\end{abstract}

Keywords: emigration, citizenship, JDC, Czechoslovakia, trust/mistrust, Holocaust survivors

DOI: https://doi.org/10.31577/forhist.2021.15.2.2

$\mathrm{T}$ his paper examines the decision-making process, parties involved and the relevant change of circumstances that influenced the decision to allow emigration from Czechoslovakia between 1945-1949. A turbulent period of life for one particular family is the focus, which in certain ways did not fit the common official and social categories, or typical classification of citizens. On one hand, the characteristics of this particular family made it difficult for the members to return to the routine of post-war everyday life, which was therefore a key motivation for them to emigrate. On the other hand, those same qualities complicated their relationship with the institutes whose duty it was to help during emigration - through procedural assistance and placement possibilities abroad. In order to be successful in the emigration process, it was required to create and maintain a level of trust - at every stage of the process-from the institutions and bodies as applicants, and to prove one's loyalty towards the officials involved. The practical goals and ideologies of the concerned institutions and bodies were manifold, and at times, even openly contradictory.

\section{Key Protagonists}

The main characters in this case are husband and wife Adolf and Erna Schwarz. Both were residents from territories which were part of Czechoslovakia in the interwar 
period, however, based on the Munich Agreement, were ceded to the Third Reich in the fall of 1938. Adolf Schwarz was born April 17, 1904 in the Silesian village of Malá Morávka, close to the city of Bruntál in the north-east of today's Czech Republic. ${ }^{1}$ Erna Schwarz, maiden name Grünhut, was born in 1909 in the city of Tachov in the west of the country. Both families identified as German, which is clear from the Czechoslovak 1930 census. Concerning religion, the couple was mixed; Adolf was Roman-Catholic and Erna was from a Jewish family. Although the couple lived in Prague, where Adolf worked, since their wedding in 1934, the institutionalized anti-Semitism intimately influenced their lives in fall of 1938 when Erna's parents were forced to flee the Nazi occupied border region of Sudety, ${ }^{2}$ finding shelter in Adolf and Erna's flat in Prague. Following March 1939, that is after the declaration of the Protectorate of Bohemia and Moravia, Nazi race persecution laws started to concern Erna as well. Her Jewish parents were deported to concentration camps in October 1941, where they both perished. Fortunately, Erna survived the Holocaust as the "wife of a Catholic" who refused to divorce her and as such was persecuted himself, even sent to a concentration camp in 1944.

\section{Struggle for Citizenship}

After liberation in May 1945, all of the racial discriminatory norms became invalid and the legal system of the state began to return to the constitutional principles of equality for all citizens before the law. What remained problematic was the actual interpretation of citizenship. Based on the Constitutional Decree of the President concerning modification of Czechoslovak citizenship of persons of German and Hungarian ethnicity (Ústavní dekret prezidenta o úpravě československého státního občanství osob národnosti německé a mad’arské), approved under law 33/1945 Sb., ${ }^{3}$ members of German and Hungarian ethnic minority were stripped of their citizenship en masse. The regulation adopted a range of vaguely defined conditions under which citizenship could be applied for and regained, such as proving one did not breach the duties of a Czechoslovak citizen, did not act against the Czech or Slovak nation, suffered under the Nazi regime or fought against the Nazi regime during the war. ${ }^{4}$ The recognition of a national minority was to be determined based on the last democratic census from 1930, when the basis for the ethnical self-identification was determined by one's mother tongue, however, there was an option of "Jewish nationality" that did not require any knowledge of the Hebrew or Yiddish language. ${ }^{5}$ Although the majority of Czechoslovak Jewry in the 1930 census declared themselves Jewish, many of them, which later fit the definition of "Jew" under the racial laws, indicated themselves to

1 Archiv bezpečnostních složek (ABS), fond (f.) 425 - Židovské organizace [Jewish Organizations], box (b.) 214, volume (vol.) 06, f. 0009, CV of Adolf Schwarz.

2 Ibidem.

3 For the full text of the Decree, see: JECH, Karel (ed.) Němci a Mad'aři v dekretech prezidenta republiky. Die Deutschen und Magyaren in der Dekreten des Präsidenten der Republik. Studie a dokumenty 1940-1945. Brno : Doplněk, 2003, pp. 314-349. For Edvard Benešs approach to the afterwar "Jewish question" in Czechoslovakia and the developments that led to adopting of the decree, see: LÁNÍČEK, Jan. Ve stínu šoa. Československá exilová vláda a Židé během druhé světové války a po ní. Praha : Academia, 2018, pp. 180-205; LÁNíČEK, Jan. Czechs, Slovaks and the Jews, 1938-48: Beyond idealisation and condemnation. Basingstoke : Palgrave Mmacmillan, 2013.

4 ČAPKOVÁ, Kateřina. Medzi vyhnáním a záchrannou akcí. Transporty německy mluvících Židu z Československa v roce 1946. In ČAPKOVÁ, Kateřina - RICHTER, David (eds.) Židé nebo Nemci? Německy mluvící Židé v poválečném Československu, Polsku a Německu. Praha : NLN, s.r.o., 2019, pp. 19-20; ŠUTAJ, Štefan (ed.) Dekréty Edvarda Beneša v povojnovom období. Prešov : Universum, 2004.

5 ČAPKOVÁ, Kateřina. Češi, Němci, Židé? Národní identita Židu v Čechách 1918 až 1938. Praha : Nakladatelství Paseka, 2013, p. 36. See also: ČAPKOVÁ - RICHTER 2019. 
be members of the majority population or part of the German or Hungarian minority. ${ }^{6}$ This arbitrary, subjective indication made at the time of the 1930 census became the criterion which defined eligibility for citizenship of the renewed state after the war. Despite explicit language that excluded citizens persecuted by the Nazi regime from withdrawal of citizenship, which was also the case of Adolf Schwarz as the "spouse of a Jew" and a person deported to a concentration camp, many times institutions at lower levels ignored the jurisdiction. Frequently, even Jewish survivors of concentration and extermination camps returning home to Czechoslovakia were refused recovery of Czechoslovak citizenship. The reason was again their declaration of German ethnicity in the 1930 census, and many of these cases were part of the forced deportation to Germany. In September 1946, The Council of the Jewish Communities in Bohemia and Moravia still considered it a victory to have negotiated an exception to the discriminatory law with the Ministry of Interior which exempted Jews from mass deportations, even if they had declared German or Hungarian nationality in $1930 .^{7}$ Though, even this did not guarantee an automatic return of their Czechoslovak citizenship without further complications. ${ }^{8}$

In the case of the Schwarz family, there was one aspect which had a negative-and seemingly decisive-influence in the evaluation of their citizenship; the conservative principle of marital law, which was introduced into Czechoslovak legislation from the former Austro-Hungarian monarchy according to which the wife after marriage "was to follow" the citizenship of her husband. ${ }^{9}$ So, during the Protectorate of Bohemia and Moravia, RomanCatholic Adolf Schwarz was, according to racial legislation, in the eyes of the state authority underprivileged as a "husband of a Jew". After the war, his ethnicity in the eyes of the public administration was the key factor in defining citizenship for both him and his wife Erna. Even though she was Jewish and Holocaust survivor, the key element was her husband's ethnic background.

While administration delays in the first months after the war could be blamed on general chaos, later the Schwarzes, once loyal to their home country, lost faith that the situation at home could be resolved. Without indubitable documents, as citizenship papers were, it became more and more difficult to sustain elementary daily needs such as housing, employment, etc. On top of it all, there was a growing tendency in domestic politics in which

6 According to data from the census in 1930, of all the Czechoslovak Jewry, $24.52 \%$ declared Czechoslovak nationality, $4.71 \%$ Hungarian, 12.82 \% German and 57.2 \% Jewish. See: LÁNÍČEK, Ján. What did it mean to be Loyal? Jewish Survivors in Post-War Czechoslovakia in a Comparative Perspective. In Australian Journal of Politics and History, 2014, Vol. 60, No. 3, p. 388.

7 In BULÍNOVÁ, Marie (ed.) Československo a Izrael v letech 1945-1956. Dokumenty. Praha : ÚSD AV ČR, HÚ AČR, SÚA, 1993, Instructions from the interior ministry for decision-taking by the appropriate organs, 1946, 13 September, Prague, pp. 55-59.

8 It is hard to determine how many of the approximately $15 \%$ of the Jewish survivors (approx. 23 thousand in Bohemia and Moravia and up to 32 thousand in Slovakia, including 8 thousand resettled Jews from Carpathian Ruthenia) from the Jewish pre-war population in Czechoslovakia originated from which nationality group. Generally, the sources speak of "thousands of people" affected by the restrictions. See: ČAPKOVÁ 2019, p. $12,15$. For different estimates see: VOBECKÁ, Jana. Demographic Avant Garde. Jews in Bohemia between the Enlightenment and the Shoah. Budapest; New York : CEU Press, 2013, p. 31; YEGAR, Moshe. Československo, sionismus, Izrael. Historie vzájemných vztahů. Praha : Victoria Publishing, 1997, pp. 61-62; NEPALOVÁ, Šárka. Židovská menšina v Čechách a na Moravě v letech 1945-1948. In Terezínské studie a dokumenty. Praha : Academia, 1999, pp. 314337; BÜCHLER, Yehoshua. Reconstruction Efforts in Hostile Surroundings: Slovaks and the Jews after World War II. In BUNKIER, David (ed.) The Jews Are Coming Back. The Return of the Jews to their Countries of Origin after WWII. Jerusalem : Yad Vashem, 2005, p. 257; SALNER, Peter. Židia na Slovensku po roku 1945 (Komunita medzi vierou a realitou). Bratislava: VEGA, 2016, pp. 40-43.

9 Constitutional Law n. 236/1920 Sb., § 16. For more details see entry: „Občanství státní“. In Slovník veřejného práva československého, Vol. 2. Brno: Polygrafia; Rudolf M. Rohrer, 1932, p. 979. 
the Communist Party of Czechoslovakia was gaining more power and influence. Continuous pressure was put on nationalizing the industry and attacking the "bourgeois elements". Adolf and Erna Schwarz were also marginalized from a "class" point of view. Erna worked as a business correspondent at various firms before marriage and after the wedding, she became a housewife. Adolf worked in a managerial position at the headquarters of a large private enterprise. After repeated, unsuccessful attempts to stabilize their status in Czechoslovakia-likely under the strain of the worsening international situation at the beginning of the Cold War-they decided on emigration.

\section{The Role of Intermediary Organisations}

According to available documents, the first intermediary institution the Schwarzes turned to was the American Joint Distribution Committee (JDC). ${ }^{10} \mathrm{~A}$ branch of this organisation active in post-war Czechoslovakia handled issues from paperwork and financial aid to legal advice, managing entry permits in destination countries and securing the boat tickets. ${ }^{11}$ They even helped with overall time management and assistance with navigation through the complicated process. The relationship between the intermediary official body, in this case the JDC, and the individual applicant was defined by the fact that even though the person was at the time stateless, he/she still had to be considered as "belonging" to Czechoslovakia. The intermediary institutions took up correspondence themselves between individual applicants and destination countries, as well as providing assistance and communication with the local Czechoslovak authorities and non-governmental organisations in the name of candidates. This brought into scope a parallel set of loyalties; the applicants sought to emigrate, to leave the country of their origin yet still needed to certify their past allegiances-activities before and during the war and other demands which could truly demonstrate their loyalty as citizens.

Concerning the choice of potential destinations, the Schwarzes opted for either the USA or Australia. There is no mention of them even considering emigration to Israel, perhaps because of the very fact that they were a mixed couple. While immigration of mixed couples to Israel was not unknown in those times, it remained a matter of special decision of Israeli authorities. There was also the possibility for the non-Jew to convert to Judaism, in practice however, Israel granted permits and welcomed mixed marriages only where the husband was Jewish. The opposite scenario was much more complicated. Historian Ivica Bumová explains the paradoxical outcome of tracing Jewish descent through the maternal line: as the war gained momentum and the state required men to enter the military forces,

10 The American Jewish Joint Distribution Committee, JDC or Joint, was founded in 1914 initially to provide assistance to Jews living in Palestine under Ottoman rule. The JDC's relief activities, emigration aid and rescue operations were critical before, during and after World War II. The organisation started to operate in Czechoslovakia in 1919-1920 and played a crucial role in mobilizing support and creating a network of social welfare services aimed at resettling Jewish survivors. For more details, see: PATT, Avinoam - GROSSMANN, Anita - LEVI, Linda G. MANDEL, Maud S. (eds.) The JDC at 100: A Century of Humanitarianism. Detroit : Wayne State University Press, 2019.

11 The United Services for New Americans (USNA) guidelines first recommended to travel by boat, as flights were usually one and a half to two times more expensive. A ship from Belgium to the United States could cost $\$ 200$ per person, the flight from Czechoslovakia was approx. \$397 per person. However, as the political situation worsened in Czechoslovakia, the JDC office used any means of transport to move refugees out of the country. Source: JDC Archives, 1945-1954 Geneva Collection, folder ORG.285, USNA Special Information Bulletin, Series II, No. 10, 30 March 1947, http://search.archives.jdc.org/multimedia/Documents/Geneva45-54/G45-54_ORG/G45-54_ ORG_033/G45-54_ORG_033_0064.pdf\#search [last viewed 1 November 2021]. 
it was considered less likely that a non-Jewish person would be reliable to risk his life for the Jewish state. ${ }^{12}$

The JDC in Prague opened the case of the Schwarz family on September 7, $1948^{13}$ and processed their request for emigration to Australia. ${ }^{14}$ The family had also requested emigration to the United States under an official annual quota defined by the US government for Czechoslovakia. They also filed an application for emigration with another international institution active in the country-the International Refugee Organization (IRO).${ }^{15}$ Coordination of emigration to the United States could also be handled via the JDC, but it seems the Schwarzes approached another institution to consider the possibility. It is unknown whether they acted on the JDC recommendation or applied on their own, simply searching for more ways of getting overseas. ${ }^{16}$

\section{Stages of the Administrative Process}

The JDC application file of Adolf and Erna Schwarz provides us with more detailed information about their private lives, qualifications and strategies of presenting themselves to particular decision-making bodies. In a document dated September 1, 1948, citizenship of the couple is still classified as "undecided". ${ }^{17}$

Assuming it was Adolf's German ethnic background, which could have been an obstacle for regaining Czechoslovak citizenship for both of them, and of course a richer career life, his file is more detailed and more defensive in wording. In 1948, he was 44 years old and as mentioned, his religion was Roman-Catholic. Living in an ethnically mixed environment, he was fluent in Czech, German and French, and had also acquired a basic knowledge of English. From July 1921 until January 1927, he worked at the Mining and Iron Company Ltd. in the city of Sobotín, $30 \mathrm{~km}$ from his birthplace and from 1927 until August 1944 in the Central Bureau of Czechoslovak Factories for Wire and Wiregoods Manufacturers Ltd. in Prague. Documents proving their employment qualifications, professional skills and experience were a mandatory part of the application for emigration and had to be verified by previous employers. Adolf Schwarz attached a letter from the Head Office of his former employer to his application ${ }^{18}$ stating that he had 23 years of experience and a very good knowledge of the production, having worked in both the workshops and the sales

12 BUMOVÁ, Ivica. Povojnové pomery židovskej komunity na Slovensku a emigrácia Židov do Palestíny/Izraela v rokoch 1945-1953. In VRZGULOVÁ, Monika - SALNER, Peter (eds.) Reflexie holokaustu. Batislava : Dokumentačné stredisko holokaustu, Ústav etnológie SAV, 2010, pp. 30-31.

13 ABS, f. 425 - Židovské organizace, b. 214, vol. 06, f. 0010, reference number 5356, Application for LP to Australia.

14 ABS, f. 425 - Židovské organizace, b. 214, vol. 06, f. 0005, JDC registration form.

15 Adolf and Erna Schwarz IRO Application for Assistance. CM/1 Forms and accompanying documents from DPs in Switzerland as well as correspondence from the International Refugee Organization (IRO) offices in Germany, Austria and the Near East with the IRO headquarters in Geneva. Doc. No. 8117292, https://collections.arolsenarchives.org/, Arolsen Archives.

16 In a letter sent from the JDC in Prague to the USNA office in New York in the same month as the Schwarzes applied for emigration, Helen Kohn explains that in August 1948, from the overall number of 120 visas allowing entry to USA issued by Czechoslovakia, only 44 were given to Czechoslovakians. The rest were issued under a quota for Jews using Czechoslovakia as a transit country by Germans, Poles and Hungarians. These figures pertained only to Jews who came to the JDC for assistance with their emigration, so the quota limit would be reached sooner including direct applicants. Source: JDC Archives, 1945-1954 New York Collection, folder AR194554, Letter from Helen Kohn to Miss Ann S. Petluck, September 06 1948, http://search.archives.jdc.org/multimedia/Documents/ NY_AR_45-54/NY_AR45-54_Count/NY_AR45-54_00019/NY_AR45-54_00019_00384.pdf\#search= [last viewed 1 November 2021$]$.

17 ABS, f. 425 - Židovské organizace, b. 214, vol. 06, f. 0010, CV of Adolf Schwarz.

18 ABS, f. 425 - Židovské organizace, b. 214, vol. 06, f. 0049, Confirmation Letter from Head Office of Wire and Wiregoods manufacturers Ltd. Prague. 
department. His segment of the industry included the production of nails, screws, wires, and cables-an assortment of goods sought after in the era of post-war reconstruction.

In October 1934, Adolf married Erna Grünhut, who was Jewish and therefore from 1939, when the Nazi-controlled Protectorate of Bohemia and Moravia was proclaimed, he was subjected to "all regulations limiting the freedom of Jews". Since he repeatedly refused to divorce his wife in the face of direct pressure, he was "sent to a concentration camp in Bystřice in Bohemia on August 31, 1944", where he remained until the end of the war. ${ }^{19}$ Sonderlager Bystřice $u$ Benešova was one of the smaller camps in the territory of Bohemia, originally meant for "jüdische Mischlinge" but later used as a detention camp for "Aryan" husbands of Jewish wives. ${ }^{20}$

The Schwarz family faced an additional burden when Adolf's parents-in-law fled the occupied Sudetenland in 1938. They lived with the Schwarzes until October 1941, when they were deported to the territory of occupied Poland where they both perished. Before Adolf's own deportation, he also engaged in regular support of prosecuted Jewish families outside his family circle. He sent food packages to various Prague based families in need and those being deported. In case the authorities doubted his efforts, he included seven names and addresses of people who could verify his claims. ${ }^{21}$ At the end of his CV, Adolf expressed a list of reasons for his decision to emigrate from Czechoslovakia in a rather "neutral" way, attempting to satisfy representatives of a prospective host country while not damaging relations with the administrative bodies of the country of his origin. He reasoned that since their "application for Czechoslovak citizenship had been refused", they were still "without citizenship at the present", he had "no other option" than to turn to an international institution for help and to emigrate to a place where he would be able to gain full citizen rights. ${ }^{22}$

Erna Schwarz, maiden name Grünhut, was born in 1909 and according to her CV, as a qualified business correspondent she was able to communicate in several languages, namely Czech, German and partially English. Prior to her marriage, she worked for various firms but after marrying Adolf Schwarz in 1934, became a housewife. For skills she mentions "fancycraft work" and taking care of children as a nurse. Despite the marriage to an "Aryan"- and even "German"- husband in February 1945, she was deported to the Terezín concentration camp where she survived until the liberation in May 1945. It is interesting to mention that her deportation came almost a half year after her husband's. Erna was sure that if she "had not been married to a non-Jewish man", she would have been "sent away earlier and would have most probably perished."23 Further hardships after the end of the war were described in her CV using the same words as her husband.

19 ABS, f. 425 - Židovské organizace, b. 214, vol. 06, f. 0009, CV of Adolf Schwarz.

20 See: ZEMANOVÁ, Věra - PLACHÁ, Pavla. Tábory pro tzv. židovské míšence a nežidovské partnery ze smíšených manželství na českém území v době 2. světové války. In PLACHÁ, Pavla. „Nepríchází-li práce $k$ Tobě - rưzné podoby nucené práce ve studiích a dokumentech. „Kommt die Arbeit nicht zu Dir" - verschiedene Formen der Zwangsarbeit in Studien und Dokumenten. Praha : Kancelář pro oběti nacismu, 2003, pp. 104-111; KAVENA, Jiří. Sonderlager pro židovské míšence v Bystřici u Benešova. In Terezínské listy: sborník Památníku Terezín 28. Praha : Oswald, 2000, pp. 51-60.

21 They were the following: Pavel Thieben, Gréta Schmiedtová, Gréta Worschechová, Milly Windholzová, O. Slapalová, Oskar Beck and E. Steinberger. See: ABS, f. 425 - Židovské organizace, b. 214, vol. 06, f. 0009, CV of Adolf Schwarz.

22 ABS, f. 425 - Židovské organizace, b. 214, vol. 06, f. 0009, CV of Adolf Schwarz.

23 ABS, f. 425 - Židovské organizace, b. 214, vol. 06, f. 0007, CV of Erna Schwarz. 
Since the couple was applying for emigration with the help of a Jewish sponsored organisation, Erna Schwarz had to prove that she was a member of the Jewish community. She enclosed a letter of confirmation from the Council of Jewish Communities in Bohemia and Moravia stating that she was of "mosaic faith". ${ }^{24}$ Both references from the employer and the religious affiliation had to be confirmed by a notary, ${ }^{25}$ which was yet another bureaucratic step and a financial expense for the family. Moreover, the demands of the JDC drove the applicants to a certain level of dependence on their former employers or religious communities and other bodies, for which they had to position themselves as individuals worth the extra efforts.

An important piece of the application was to provide a sponsor who would cover the future emigrants' expenses for transport, or at least part of it, and help them financially or with accommodation upon arrival. The JDC had funds ready at their disposal, however, the demand was much larger than the available resources. The organization did not only finance travel costs for emigration from Czechoslovakia, but also paid for housing, food supplies, medical treatment and many other necessities of Jewish survivors living in Czechoslovakia at the time. Therefore, it was very welcome if the émigrés had their own financial cover, or had relatives or acquaintances to sponsor their trip and initial living expenses. In the application, the Schwarzes stated that they have no financial means to pay for the transportation costs on their own in Czechoslovak crowns. Two relatives were named as potential sponsors, "cousin and sponsor" J. E. Gurry (5 Fairbairn rd., Toorak, S.E.2, Melbourne) in Australia and "cousin" Richard Neubauer (Transcrit Corporation, New York, N.Y.) in the United States. They expected these two would be willing and able to fund their trip to Australia. The relatives abroad could also have been seen as a form of success story, which could have triggered the decision to emigrate and where to emigrate to. According to research done in 1965, $68 \%$ of Czechoslovak Jewish families claimed to have close relatives in foreign countries. Because of the holocaust, they considered whomever from the family-even the most distant relatives - close connections. ${ }^{26}$ Viewing emigration as the breaking moment for their future life and counting on the opportunity to repay everything once their goal was reached, they turned to those relatives for everything the institutions requiredfinances, future accommodation and possible positive references. Presenting an existing anchor in the form of a relative willing to guarantee support was an important asset in the eyes of the receiving country's administration.

\section{The "Head of the Family is a Roman Catholic..." Issue}

Meanwhile, due to further developments in the Cold War, the numbers of immigration candidates multiplied ${ }^{27}$ and the composition of the applicant group changed

24 ABS, f. 425 - Židovské organizace, b. 214, vol. 06, f. 0011, The confirmation from Council of the Jewish Communities in Bohemia and Moravia. See also: ABS, f. 425 - Židovské organizace, b. 214, vol. 06, f. 0012, Questionnaire for persons of Mosaic confession.

25 ABS, f. 425 - Zidovské organizace, b. 214, vol. 06, f. 0050, Notary confirmation.

26 SALNER, Peter. Zmeny hodnotových orientácií Židov na Slovensku po roku 1945 (na príklade emigrácie do Izraela v štyridsiatych, resp. šesṫdesiatych rokoch). In SALNER, Peter (ed.) Židovská komunita po roku 1945. Bratislava : Ústav etnológie SAV, 2006, p. 103.

27 Democratic Senator Alexander Wiley of Wisconsin on June 2, 1948, expressed during a debate in the US Senate, "This is America, our home. We want good blood to come to this country but we do not want any 'rats'-we have enough of them." His Republican counterpart, Senator Robert F. Rich of Pennsylvania, continued on June 10, 1948, "I am unalterably opposed to the opening of the doors of this country to everyone who wants 
dramatically. ${ }^{28}$ While shortly after the war, potential émigrés with Jewish backgrounds were seen as escaping Nazi terror, later on, camps in Allied zones in Europe were filled with refugees escaping the rising communist threat. The first law admitting refugees into United States ${ }^{29}$ was commonly known as the DP Act of 1948. It granted Czechoslovakia a different condition. The country is mentioned specifically, and an "eligible displaced person" is defined as "a native of Czechoslovakia who has fled as a direct result of persecution or fear of persecution from that country since January 1, 1948..." 30 The law was tailor-made to respond to changes that took place in Czechoslovakia after February 1948 with the communists taking over and addressed its natives who have "fled as a direct result of persecution or fear of persecution from that country since January 1, 1948". ${ }^{11}$ Still in Czechoslovakia in September 1948 and waiting for finalization of their paperwork, the Schwarzes were becoming latecomers. Fortunately, for people like them, the deadlines for eligibility were not observed rigidly and therefore the process of emigration from Czechoslovakia to the USA could continue, at least in a limited manner.

After verification of their documents, the JDC began the process of possible emigration within their network, notifying partner institutions in the countries which the Schwarzes listed as possible future destinations. The local organisation was to contact the potential sponsors, who would then vouch for the family and cover the costs of their transport. Head of the Emigration Department of JDC Czechoslovakia Helen Kohn (also Ellen Cohen), notified the Jewish Welfare and Relief Society (JWRS) in Australia in a letter dated September 22, 1948, about the Schwarzes' case. A letter from the JDC in Prague contains a request for the partner institution to contact a person by the name of J. E. Gurry, who by this time was already in personal contact with the Schwarzes. Gurry was to arrange an "LP" (Landing Permit) to Australia. Additionally, the JDC in Prague asked the Jewish Welfare and Relief Society to help Mr. Gurry to process and speed-up the arrangement. Lastly, Helen Kohn requested that Mr. Gurry make a deposit towards the transportation costs from Czechoslovakia to Australia amounting to approximately 1500 dollars. $^{32}$

to come to America from some foreign country [...] I am not going to throw the doors wide open and permit America to be the dumping place for all humanity." Quoted from: NASAW, David. The Last Million. Europe's Displaced Persons from World War to Cold War. New York : Penguin Press, 2020, pp. 412, 415-416.

28 For the impact of the DPs and other immigrants on American policy making, see: KOCHAVI, J. Arieh. PostHolocaust Politics. Britain, the United States and the Jewish Refugees, 1945-1948. Chape Hill, London : The University of North Carolina Press, 2001, pp. 89-130. See also: GENIZI, Haim. America's Fair Share: The Admission and Resettlement of Displaced Persons, 1945-1952. Detroit : Wayne State University Press, 1993.

29 Signed by President Harry S. Truman on June 25, 1948, officially Public Law 80-774.

30 The formulation stated that anybody, who at the beginning of 1948, was a native of Czechoslovakia and entered any of the Allied dedicated sectors in Germany or Austria by June 1948 was eligible for admittance to the United States. In practice, the deadline for eligibility was in most cases not observed. The process of emigration from Czechoslovakia to the USA could therefore continue and the DP act of 1948 was applied to migrants as well as for DPs already in dedicated camps. For the Soviet zones and the migration policies of USSR, see: POLIAN, Pavel. Against Their Will: The History and Geography of Forced Migrations in the USSR. Budapest; New York: CEU Press, 2003, pp. 115-164.

31 The limitation of the Act was that "upon the grant of status of permanent residence to such alien as provided for in this section, the Secretary of State shall, if the alien was a quota immigrant at the time of entry, reduce by one the immigration quota of the country of the alien's nationality as defined in Section 12 of the Immigration Act of May 26, 1924." It discriminated against people on the immigration quota waiting lists set by previous regulations for every individual country to be potential new immigrants by transferring their places under this DP Act, limited to 200 thousand people overall, regardless of native state. Source: Pub. L. 80-774, https:// uslaw.link/citation/us-law/public/80/774 [last viewed 1 November 2021].

32 ABS, f. 425 - Židovské organizace, b. 214, vol. 06, f. 0047, Letter from Helen Kohn to Jewish Welfare and Relief Society in Melbourne. 
A similar letter was sent to another partner institution in United States, the United Services for New Americans (USNA). ${ }^{33}$ Again, Kohn introduced the case and requested Richard Neubauer to be contacted, and also asked to determine if he is willing and able to contribute towards the transportation costs of their planned immigration to Australia, in the same amount of 1500 dollars. The only difference between the two letters is that the one to the United States mentioned the religious affiliation of the spouses i.e., Mr. Schwarz being Roman-Catholic and Mrs. Schwarz as Jewish. ${ }^{34}$

On October 18, 1948, the JDC office in Prague received a response signed by Ann S. Petluck, ${ }^{35}$ the Head of Migration Services at USNA, which almost brought the Schwarzes application process to an end. Before approaching "the local cooperating committee with the request that they contact the interested relative," Petluck asked for clarification of a "serious question, as to whether this case should be handled by our agency". ${ }^{36}$ In the understanding of the USNA, this case did not belong to their portfolio since "the head of the family is a Roman Catholic" and demanded an explanation why it was not referred to a relevant Christian agency. This approach was by no means exceptional.

The Secret Service Archive in Prague contains another letter, primarily dealing with the case of the Janovic family, ${ }^{37}$ though also related to the Schwarzes. In this case, it was the "Australian Committee" which objected to the husband in the family not being Jewish. In defence of the people the JDC in Prague represented, Helen Kohn described the situation on the ground in a series of letters addressed to the Headquarters of the JDC in Paris, the USNA in New York, the United Jewish Overseas Relief Fund in Australia and to the headquarters of the JDC in New York. Kohn noted that in the local communities, there were "many persons living in mixed marriages where one member of the family is non-Jewish, the other Jewish and a member of the Jewish Community. We do not make any general decisions but consider each case individually." She tried to further strengthen her arguments by listing the deeds of the non-Jewish head of family helping Jews during the war in Prague. She explained that there was a rule to be taken into consideration, "not only to question the local applicants Jewishness, but also the religion of the sponsor abroad and his position in the community, as we feel" she stated, "it often involves a very serious matter in public relations [...] The sponsors abroad likewise are Jewish." She stated that the applicants must be evaluated case by case as they in Prague do not make "any general decisions but consider each case individually."

The letter continues with an attempt to secure financial aid for the Schwarz case and their journey. Kohn stressed that both Mrs. Schwarz and the potential sponsor, Mr. Neubauer in New York, were Jewish, considering it a legitimate reason for turning to the USNA for assistance. "We understand, of course, that in the United States the religion of the husband is considered the family religion, this is not generally true here.

33 In the letter to Australia, Helen Kohn referred to the organization as UNISERNA.

34 ABS, f. 425 - Židovské organizace, b. 214, vol. 06, f. 0048, Letter of Helen Kohn to USNA in New York.

35 Ann S. Petluck was a lawyer specializing in emigration and a "refugee expert". From 1951 to 1954, she was director of the USNA and from 1954 to 1964, she directed the United States operations for the United HIAS Service (Hebrew Immigrant Aid Society). Between 1964 and 1968, she served as deputy regional representative at the United Nations for the High Commissioner for Refugees (UNHCR).

36 ABS, f. 425 - Židovské organizace, b. 214, vol. 06, f. 0044 and f. 0043, Letter from Ann S. Petluck from USNA to JDC Prague.

37 ABS, f. 425 - Židovské organizace, b. 214, vol. 06, f. 0039 and f. 0040, Letter from Helen Kohn to JDC Paris $E E H$. 
There also is no Catholic agency here that deals in matters of emigration." ${ }^{38}$ Interestingly, Helen Kohn did not mention - and nobody seemed to take into considerationthe fact that both Mr. Schwarz and Mr. Janovic are, although non-Jews, survivors of concentration camps. They have both been deported as "Aryans" who refused to divorce their Jewish wives.

In the meantime, the pressure of the Czechoslovak government toward the JDC grew. Authorities requested ever increasing payments in dollars for regular administrative work, complicated paperwork requests and created new fees and tolls to extort money from the JDC budget. Prospective emigrants were almost openly targeted as hostages. In this way, the government deepened the mistrust between them and the state and showed that it had no longer any interest in them as citizens. The bullying went so far that in 1948 and 1949, some important, high-ranking individuals were arrested and the Czechoslovak authorities requested immense sums of money for their release. ${ }^{39}$

The never-ending emigration process, the endless number of documents and uncertain outcome resulted in the Schwarz family doubting their decision to leave for Australia with the help of the JDC. While the agency never gave the Schwarzes reason to doubt that it acted in their best interest, in light of the complicated and seemingly desperate situation involving both the Czechoslovak state and the international institution handling the case, they suspended relations with the JDC as an intermediary but continued to communicate with the sponsor in the USA on their own.

Then, almost four months after the last communication in the Schwarzes case, on March 4, 1949, a letter arrived from the United States in which the USNA informed the JDC office in Prague that agents of the organisation were in touch with Mr. Neubauer who would be ready to pay transportation and he himself is in correspondence with the "overseas clients". Mr. Neubauer indicated that he had the impression from recent correspondence the Schwarzes no longer wished to continue with the Australia plan. "He [Richard Neubauer] understands that they now plan to wait for their regular Czech[oslovak] quota number for United States immigration." ${ }^{40}$ The JDS's Prague office should either reject or verify these claims. Finally, in June 1949, the long-awaited LPs to Australia for the Schwarzes arrived, ${ }^{41}$ which was yet again arranged by a private person-Mr. Gurry.

The following months became enormously stressful for the Schwarzes. There was immense pressure to speed up the process for two reasons: one being legal and the other political. With a growing number of refugees from Europe and a limited number of spots available on boats, there were numerous instances when the issued LP expired before the refugees reached their destination. This was an issue between the organisations involved and was dealt with in internal communication as well as with the respective ministries in the concerned countries. ${ }^{42}$

38 Ibidem.

39 Among the arrested was the director of the JDC office in Bratislava, Juraj Revesz. They were released a few months later after the intervention of Joseph J. Schwartz, who flew in from Paris. According to Martin Šmok, Schwartz most likely paid up to 5 million Czechoslovak crowns for their release. See: ŠMOK, Martin. Tajemná smrt v Praze, prípad Charlese Jordana. (manuscript).

40 ABS, f. 425 - Zidovské organizace, b. 214, vol. 06, f. 0034 and f. 0038, Letter from USNA to JDC Prague.

41 ABS, f. 425 - Židovské organizace, b. 214, vol. 06, f. 0025, LP information.

42 In Australia, according to information from the Executive Council of Australian Jewry, who took credit 
The political situation in Czechoslovakia changed dramatically with every passing week and the authorities made it harder to even secure a boat ticket. A report from JDC Prague to Paris headquarters stated that Czechoslovak citizens could only book a boat ticket if the given boat is registered with the local Ministry of Labour and Social Welfare and if it fulfils criteria defined by Czechoslovak law. ${ }^{43}$ Reports from Prague stated that "usual purges in the army, justice, schools, church administrative bodies [...] and public administration took place. Entry and exit permits, passports and visas are more difficult to obtain." Furthermore, the executive committee of the Council of Jewish Communities in Bohemia and Moravia was overtaken by communist appointees and the Council "refused to provide food supplies and accommodation paid by us to persons who entered Czechoslovakia illegally [...] which puts them at risk of persecution of the police." ${ }^{4}$ The JDC in Czechoslovakia operated under very restricted conditions with ever diminishing resources.

On July 11, 1949, the Australian offices made an announcement to the JDC office in Prague concerning the case of the Schwarz family that their "Migration Committee considered this case. However, as Mr. Schwarz is not Jewish, we are unable to handle this case." 45 The decision again failed to recognize Mr. Schwarz eligible because of his confession. The relief institution in Australia closed their case definitely. The Schwarzes were invited to a meeting at the JDC offices, which marked a full year since they first applied for emigration. Based on the August 12, 1949, report, we know that in the meantime, Mr. Schwarz was employed as a clerk in the state company Centrotex, dealing in the export and import of textiles, ${ }^{46}$ earning a monthly salary of $4500 \mathrm{Kčs}$. He was unemployed in 1948. The couple lived in modest surroundings and reconfirmed that they did not own any particular means. Especially mentioned are "furs, jewellery and Persian carpets", which they did not own. ${ }^{47}$ They lived in a one room apartment which they rented for 4800 Kčs per year. Whether the couple would be able to cover the necessary financial difference for transportation depended on whether they would be able to sell the furniture and equipment from their apartment. ${ }^{48}$ The Schwarzes intention of selling the property might also have been a difficult task. In one of Helen Kohn's reports, she addresses this issue:

In the course of emigration, the Jews are systematically being robbed: the state regulation allows them to only keep basic necessities and clothing, from both they are only allowed to take on the journey up to $100 \mathrm{~kg}$. Apartments, furniture, valuables, all mate-

for the negotiations, the Australian Immigration Minister has promised to issue instructions to the various legations that the expired visas should be renewed. Source: Center for Jewish History, United Service for New Americans Records, b. 23, folder 17 (I-93), Special Information Bulletin, 1946-1954, https://digipres.cjh.org/ delivery/DeliveryManagerServlet?dps_pid=IE1135872 [last viewed 2 November 2021].

43 See: ŠMOK, Tajemná smrt v Praze (manuscript).

44 All quoted from: ŠMOK, Tajemná smrt v Praze (manuscript).

45 ABS, f. 425 - Židovské organizace, b. 214, vol. 06, f. 0026, Letter from JWRS in Australia to JDC in Prague.

46 ABS, f. 425 - Židovské organizace, b. 214, vol. 06, f. 0017, Report from the meeting, August 12, 1949 (English translation f. 0018).

47 Helen Kohn mentioned the restriction in summer 1948, "it is still prohibited to export carpets, silver, gold or gems, it is also prohibited to export expensive clothing and fur coats." Quoted from: ŠMOK, Tajemná smrt v Praze (manuscript).

48 ABS, f. 425 - Židovské organizace, b. 214, vol. 06, f. 0017, Report from the meeting, August 12, 1949 (English translation f. 0018). 
rial possessions acquired since the return from the concentration camps must remain here and cannot be sold. ${ }^{49}$

This must have resulted in the Schwarzes selling their belonging on the black market, which added more danger to the already difficult situation, were they to be caught by police.

On a JDC copy of an invitation for the Schwarzes to report to the organisation's office in Prague, there is a hand-written note on the reverse side mixing English and Czech. It states that the Schwarzes "are willing to pay the outstanding sum of transportation costs in Czechoslovak crowns by own funds. They have not made the final decision about emigrating. She will come in four weeks to announce her final decision. Date: 15/VII.49. [illegible signature]" ${ }^{\prime 0}$ It is not clear if these were two different encounters or added information from the meeting on August 12, 1949, though, this document is the last concerning the Schwarz family. Currently, there is no evidence in the Schwarzes file whether they finally emigrated to either Australia or the United States, or remained in Czechoslovakia.

\section{Conclusion}

The case of the Schwarz family illustrates the complex relationship and mutual trust/ mistrust of all actors involved in the process of emigration. The couple's attempt to leave Czechoslovakia with the assistance of the JDC provides a variety of insights into the functioning of current social networks.

For the purpose of this research, it is secondary whether the family succeeded or failed in their attempt to leave the country. Rather, the chain of interlinked events and shifting loyalties is detailed, occurring between the individuals, intermediaries, donors and the state.

For people like the Schwarzes, the end of the war did not end the hardship and did not bring the "normality" they remembered from times before the war. The Nazi regime defined them based on racial principles and for Erna Schwarz as a Jew and Adolf Schwarz as an "Aryan" husband of a Jew, they were pushed into an unprivileged and persecuted group of society with both being deported to concentration camps. Practically right after the war, the re-established state of Czechoslovakia defined loyalty towards the country by deciding who could be and could not be a citizen, imposing another limitation upon people like the Schwarzes-the ethnic definition of citizenship. Arbitrary information about one's mother tongue-i.e., ethnicity-in the pre-war census, which was not a precondition to citizenship, became an obstacle in their claim to Czechoslovak citizenship. Many Jewish Holocaust survivors who grew up in traditionally German or Hungarian-speaking environments once again became second-rate citizens, or no citizens at all. On many occasions, official decisions pushed them into the same group with non-Jewish ethnic Germans and Hungarians, which were to be deported to Germany and Hungary. Only thanks to the efforts of renewed Jewish institutions, such as the Council of Jewish Communities in Bohemia and Moravia, they were successful-

49 ŠMOK, Tajemná smrt v Praze (manuscript).

50 ABS, f. 425 - Židovské organizace, b. 214, vol. 06, f. 0014, Handwritten report. 
ly exempted from it happening. This accentuates the importance of such institutional representation for marginalized groups.

The paper outlines the state as a political power, which set quotas, regulations and bureaucratic obstacles as well as granted visas, permits and new/renewed citizenships. Those excluded from the right to citizenship had to navigate through a complicated framework set for them by laws and decrees. Their stateless status left the Schwarzes no other option but to look for possibilities to emigrate and transfer their loyalty to a new state. It forced them to adopt new strategies of how to stabilise their situation at home in the renewed state, to confirm their own acceptability on the local level-in the eyes of the state authorities, regional official bodies, former employers, the Jewish community etc., while at the same time seeking help outside the boundaries of the state-with intermediary organizations, in this case the JDC and its network, or relatives and acquaintances abroad.

With regard to everyday life and interaction with the authorities, the Schwarzes found themselves in a "schizophrenic" situation. On one hand they had to assure the Czechoslovak state bodies of their allegiance and loyalty, to portray themselves "worthy" of the Czechoslovak citizenship they had applied for, yet on the other hand, they endeavoured to assure the foreign guarantees and the destination state of their best intentions in the future.

With the changing climate of the Cold War and the political changes within Czechoslovakia after the February 1948 coup d'état, the couple's possibilities narrowed dramatically. The pressure of the state against the JDC and other organisations increased steadily and slowly made their activities impossible. It became harder to assist people in their emigration attempts and moreover, they had to conduct other activities illegally. All measures against the JDC were by proxy also steps taken by the state against its (former) Jewish citizens, which it had given up on and even used them as "hostages" in pressuring international institutions.

Records of the emigration process of this family case study end in September 1949. The JDC office in Prague closed at the beginning of 1950 with a message sent from Prague to the Paris headquarters: "All operations of the JDC in Czechoslovakia will cease on January 31, 1950, based on a formal request from the Czechoslovak authorities." ${ }^{1}$ The JDC offices were sealed by the secret police and almost all paperwork was confiscated by the state secret police (Státní bezpečnost - StB). The JDC offices were, to a certain extent, shut down because it was a Jewish organisation which had helped the Jews of Czechoslovakia flee the country, but mainly because it was an agency from the United States of America. The decision was motivated by both anti-Semitism and a growing anti-Zionism, but also by the fact that throughout the Cold War, the US and its allies represented the absolute enemy of the communist regime.

Despite the presence of anti-Semitic tendencies on all levels of society in post-war Czechoslovakia, a significant number of citizens of Jewish descent were able to find employment in state apparatuses in the early years after liberation. These people could strengthen their political capital through their own personal histories-they were

51 Quoted from: ŠMOK, Tajemná smrt v Praze (manuscript). 
members of Czechoslovak army units at the Western or Eastern front, fought in the Slovak National Uprising, etc. In light of these facts, the relationship of the official bodies towards Jews of German ethnicity was driven not only by anti-Semitism, but rather by an anti-German sentiment following six years of Nazi occupation. Even in this key question of returning citizenship to ethnic Germans, the decree of the government no. 252/1949 Sb. significantly eased the process. Although the mistrust of civil servants at the lesser regional departments still prevailed and the process was sabotaged, it improved at the beginning of 1950's with the circular letter distributed by the Ministry of Interior on "How to deal with the people of German minority" ${ }^{2}$ considered the culminating development in the relationship towards the local Germans.

Regarding the relief organisations, even though they worked internationally, their function was limited by the rules and circumstances of the specific country and its internal political situation. The possibilities and limitations of such international institutions and their relationships with individuals offer a broad variety of topics for further exploration, for example in a comparative perspective within Central Europe-looking into the processes and work of the JDC and other institutions in Poland, Hungary or Romania. Comparing their inter-connectedness and coordination would shed more light on the complex and complicated involvement in this geographical space or further elaborate on the bridge between the institution and individual.

52 PETRÁŠ, René - NOVÁK, Petr. Nemecká menšina v Československu 1948-1989. In Právněhistorické studie, 2016, Vol. 46, No. 2, pp. 169-170.

\section{Cite:}

HYRJA, Jozef. "As Mr. Schwarz is not Jewish, we are unable to handle this case." Elements of (Un)Success in Overseas Emigration from Post-war Czechoslovakia. In Forum Historiae, 2021, Vol. 15, No. 2, pp. 11-24. ISSN 1337-6861. DOI: https://doi.org/10.31577/forhist.2021.15.2.2

Jozef Hyrja

Historický ústav SAV

P. O. Box 198, Klemensova 19

81499 Bratislava

email: jozef.hyrja@savba.sk

https://orcid.org/0000-0001-9170-1846 